\title{
Implementation of Six Sigma to Minimize Reject Gusset Difference and Fold in the Blowing Process
}

\author{
Nuur Apriliani Rahayu and Sugeng Santoso
}

\section{ABSTRACT}

PT. Elastis Reka Aktif including companies engaged in manufacturing made from rHDPE (recycling High Density Polyethylene). The problem that often occurs is that the achievement of the Not Good Key Point Indicator exceeds the tolerance given by management by $1 \%$. Therefore, improvements were made using the Six Sigma method and the Failure Mode Effect Analysis method in order to get the priority of improvement targets. The first improvement proposal given to the company is for RPN 280, namely the material characteristics are not homogeneous by proposing a re-design of the silo which is in the pelletizing process and the fourth is RPN 252 where the roll takeup and winder positions are not parallel, namely by providing area boundaries in order to minimize the position not being aligned. parallel. After providing a proposal for each potential problem and socializing it to the production side, it is hoped that it can reduce the reject rate in the blowing process.

Keywords: Key Point Indicators, Six Sigma, FMEA.

\author{
Submitted : June 09, 2021 \\ Published : July 01, 2021 \\ ISSN: $2507-1076$ \\ DOI: $10.24018 / \mathrm{ejbmr} .2021 .6 .4 .913$ \\ Nuur Apriliani Rahayu* \\ Master of Management, Mercu Buana \\ University, Jakarta, Indonesia. \\ (e-mail: aprilapriliani17@gmail.com) \\ Sugeng Santoso \\ Master of Management, Mercu Buana \\ University, Jakarta, Indonesia. \\ *Corresponding Author
}

\section{INTRODUCTION}

The industrial world has now developed a lot, and each industry is required to be able to compete for its intended customers. For this reason, every industry requires the main key, which is to be able to create products with good quality compared to its competitors in order to appear satisfied (satisfied) from customers who are finally able to bring back customers and make them keep choosing the product. The method that the company can use to win the competition is a production system that is continuously being developed.

Customers are the essensial elements of every line of business, customers are also a determining factor for the existence of a company [16]. Through existing competition, there are demands for companies to always be oriented to their main goal, namely customer satisfaction. Besides having an impact on the quality of the standards being met, this quality control will also have an effect on the low price of the product [9].

This reduction in defective or damaged products results in reduced costs of the product. Here the research is carried out to improve the quality so that the industry always improves and improves the quality of its products.

To minimize the existing NG, many methods are implemented. Six sigma is a tool used by companies or organizations to identify and reduce waste to achieve six sigma through products (output, work in process, materials) that are streamed and information using a pull system (pull system) from external and internal customers. to achieve perfection and excellence by producing only 3.4 defects per 3.4 DPMO (Defects Per Million Opportunities) or one million opportunities [12].
PT Elastis Reka Aktif Now a company which is engaged in recycling plastic bags made of rHDPE (High Density Polyethylene recycling), there are 3 processes that are passed to produce plastic bags, namely the process of Pelletizing, Blowing (Blow Film), and Cutting.

In a series of processes that exist at PT. Elastis Reka Aktif must be maintained and controlled so that the quality of the process and product meets the existing standards. The Quality Assurance (QA) department is a department that has responsibility for product quality so that it becomes the performance achievement of the QA department. There are several indicators of achievement of Key Performance Indicators (KPI) that must be improved, namely the number of returns, timeliness of calibration, and the achievement of NG for each process. Here is Fig1. Average NG Percentage Achievement in the 2018-2020 Blowing Process.

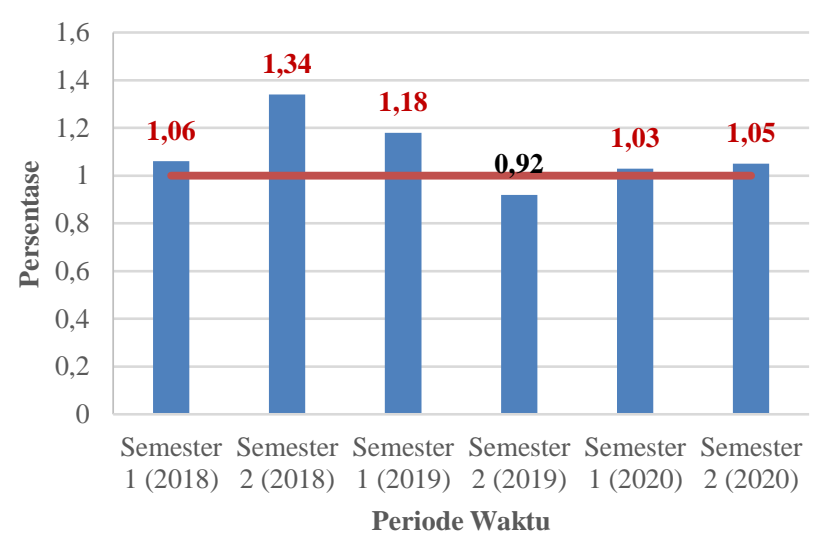

Fig. 1. Average NG Percentage Achievement in the 2018-2020 in Blowing Process. 
To find out the importance of the problem, improvements were made, where the percentage of NG each semester from semester one in 2018 to semester one in 2020 still fluctuated in achievement where each semester exceeded the maximum tolerance given by the Board of Directors of PT. Elastis Reka Aktif is $1 \%$ for the achievement of $\mathrm{NG}$ in the blowing process.

Barr chart creation in Fig. 1. carried out to find out the importance of the problem to be repaired, where the percentage of NG each semester from semester one in 2018 to semester one in 2020 still fluctuates in achievement where each semester exceeds the maximum tolerance given by the Board of Directors of PT. Elastis Reka Aktif is $1 \%$ for the achievement of NG in the blowing process.

This proves that the control in the blowing process has not been maximized, so it is necessary to analyze the root causes of the problems that occur and provide improvements so that problems in process variations can be minimized. Then PT. Elastis Reka Aktif is required to improve competitiveness strategy by taking into account the quality aspect. To improve product quality, PT. Elastis Reka Aktif must be able to reduce defects that arise in the product. The causes of defects that arise due to disturbances, ranging from small to the largest scale, disturbances are usually caused by machines, humans, methods, materials, and the environment.

So by using the Six Sigma method it can be seen what factors influence and cause the occurrence of reject products whose purpose is to reduce reject products using fish bone as a supporting method to find the root cause of the problem, and the FMEA method will provide information on reject priorities that must be improved, namely reject products produced in the blowing process and in order to be a proposed improvement to the company using the Six Sigma method. FMEA is one of the methodologies used to identify, predict, and evaluate a process, system or design by giving a score or value that describes the potential for failure based on the level of occurrence (occurrence), how severe the effect of the failure (severity), and how easy it is the failure can be detected and estimated [14], [17], [18].

\section{LITERATURE REVIEW}

\section{A. Quality}

Quality in academia and business is a common topic of discussion. It is said that an item or service has good quality if it is in line with the wishes of its consumers. Basically, quality refers to a number of experts who have many definitions and definitions, including:

1) The vocabulary of ISO 8402 and from the Indonesian National Standard (SNI 19-8402-1991), Quality is all the characteristics and characteristics of a service or product whose ability can satisfy a need, disguised, or emphasized.

2) Quality is the totality of characteristics and forms of services or goods that show their ability to satisfy needs, both visible and invisible [2].

3) Deming [4] "Quality should have a purpose as to meet the needs of consumers in the future as well as the present."

4) Crosby [3] "Quality is conformity with what consumers need including effectiveness, maintainability, reliability, delivery, and availability cost."
5) Juran [8] "Quality is the congruence of benefit and purpose.

\section{B. Six Sigma}

Sigma is a symbol that comes from Greece, namely in the field of statistics it is a symbol of deviation (standard deviation). The word Six shows the number of standard deviations above the proper specification mean [10]. Six Sigma can be used in business and manufacturing media to avoid variability and process defects. Examples of its use are improving the quality of customer service, increasing forecasting capabilities, improving logistics, reducing cycle times to hire new employees, and as increasing deliveries to be more precise [9]. The following describes the achievement of the sigma value based on Defect Per Million Opportunity (DPMO).

TABLE I: SIGMA VALUE

\begin{tabular}{cc}
\hline \multicolumn{2}{c}{ TABLE I: SIGMA VALUE } \\
\hline Sigma Achievement Rate & DPMO \\
1- Sigma & 691,462 \\
2- Sigma & 308,538 (Indonesian industry \\
3- Sigma & average) \\
4- Sigma & 66,807 \\
5- Sigma & 6210 (USA industry average) \\
6- Sigma & 233 (Japan industry average) \\
& 3.4 (world-class industry) \\
\hline
\end{tabular}

A number of opinions explain that the Six Sigma approach is skilled enough to solve quality problems masalah [5]. Because $90 \%$ of quality problems can be handled with 7 basic tools of quality. While the other $10 \%$ require analytical techniques and training from the Six Sigma approach [13].

In order to carry out the Six Sigma process, there are a number of methods designed to be used as a reference in solving quality problems, including the DMAIC method (Define, Measure, Analyze, Improve, Control). In short, the define stage generally selects the processes that need improvement. The measurement stage carries out a quantitative process translation by assessing the current performance that has been collected. The analyze stage is identifying the root cause and setting performance goals, then realizing the solution after the evaluation is carried out on the process in order to reduce the factors causing defects in the improvement step. And finally, the control stage, as an improvement so that it continues to be monitored and standardized solutions are implemented [4].

\section{DMAIC Method}

DMAIC is part of a procedure that is widely used to solve process improvement and quality improvement problems permasalahan [7]. DMAIC is widely associated with Six Sigma activities, and almost all Six Sigma implemented using the DMAIC approach [5].

\section{FMEA (Failure Mode and Effect Analysis)}

Initially, on November 9, 1949, the FMEA discipline underwent development in the United States Military, namely Military Procedure MIL-P-1629, entitled Procedures for Performing a Failure Mode, Effects, and Critically Analysis. FMEA is a methodology used in analyzing and looking for various failures that may occur in a process, then looking for the impact of these failures, and initiating efforts to reduce and improve the failure and impact on the system. 
If the failure method can be eliminated, the FMEA method will be able to bring an increase in the reliability of the product, therefore customers will be satisfied with the product. There are a number of steps in creating an FMEA:

1) Identify services/products or processes.

2) List potential problems that could arise, their causes and effects. Here trivial problems must be avoided.

3) Perform an assessment of detectability (Detection), probability of occurrence (Occurance), and severity of the problem (Severity).

Performing the calculation of the Risk Priority Number (RPN) obtained by multiplying the three variables in the previous three points and determining the solution plan to be implemented.

\section{Methodology}

The research entitled "Implementation of Six Sigma to Minimize Rejects in the Blowing Process at PT. XYZ" aims to identify various factors that have an impact on the quality of the blowing process and provide suggestions for improvement after identifying the dominant factors that occur at PT XYZ using the Six Sigma and FMEA methods. This research is included in the mix method research, namely the research method by combining two research methods at once, qualitative, and quantitative in a research activity, so that more comprehensive, valid, reliable, and objective data will be obtained. The methodology includes primary and secondary data [15].

The design used in this study is a descriptive exploratory method. What is meant by descriptive method is research with problem solving that is widely explored about the causes or things that affect the occurrence of something based on the facts that occur in the field.

\section{FINDING AND DISCUSSIONS}

\section{A. Define}

The Define stage is the first step of the DMAIC stage, and what should be carried out is identifying problems for improvement. Next, do a process mapping, namely SIPOC diagram, then VOC (Voice of Customer) analysis to identify items related to the CTQ (Critical to Quality) process to meet market or consumer desires.

As for the CTQ of the Blowing process, there are 20 items, namely the production results should not be in the products of the Blowing process.

Broadly speaking, the SIPOC map explains various important elements in a process and makes it easier to explain how to increase value, how to getinput, who is served by the process, and who are the main actors of the ongoing process. The SIPOC diagram for the Blowing process as in Fig. 2.

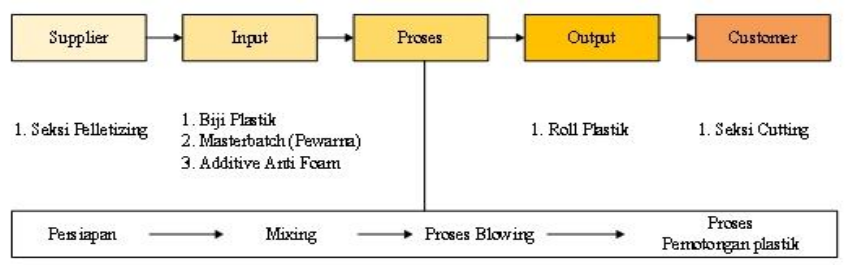

Fig. 2. SIPOC Process.
In this case, to focus the research, the reject data in semester 1 in 2018 to semester 1 in 2020 for percentages exceeding the standard tolerance of $1 \%$ will be corrected as in Fig. 3.

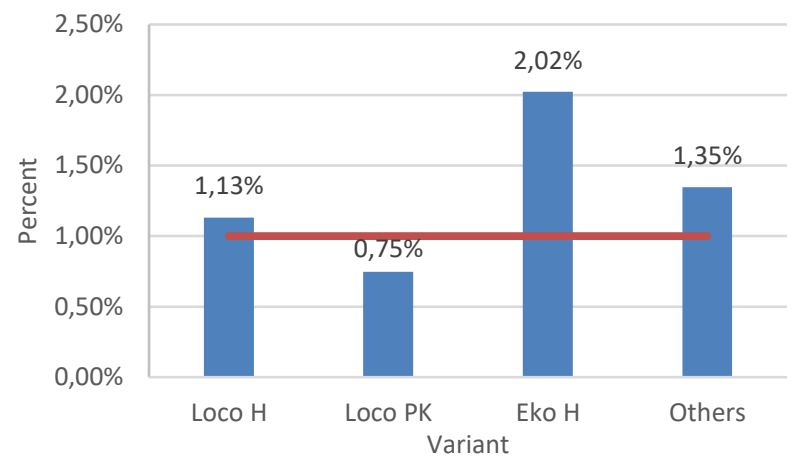

Fig. 3. Troubled Variant Histogram.

\section{B. Measure}

At this stage is the second step of the DMAIC stage, which is carried out at this stage is to measure the level of performance that becomes baseline from the initial work before doing improve. The activities carried out here are:

1) Carrying out process control with $X$ and $R$ control maps in the first semester of 2018 to the first semester of 2020 can be seen in Fig. 4.

2) Measure baseline performance in a period of five semesters from the first semester in 2018 to the first semester in 2020, what is measured is the level of DPMO and sigma level. Based on the results of the calculations, the $\mathrm{X}$ and $\mathrm{R}$ control charts are presented in Table II.

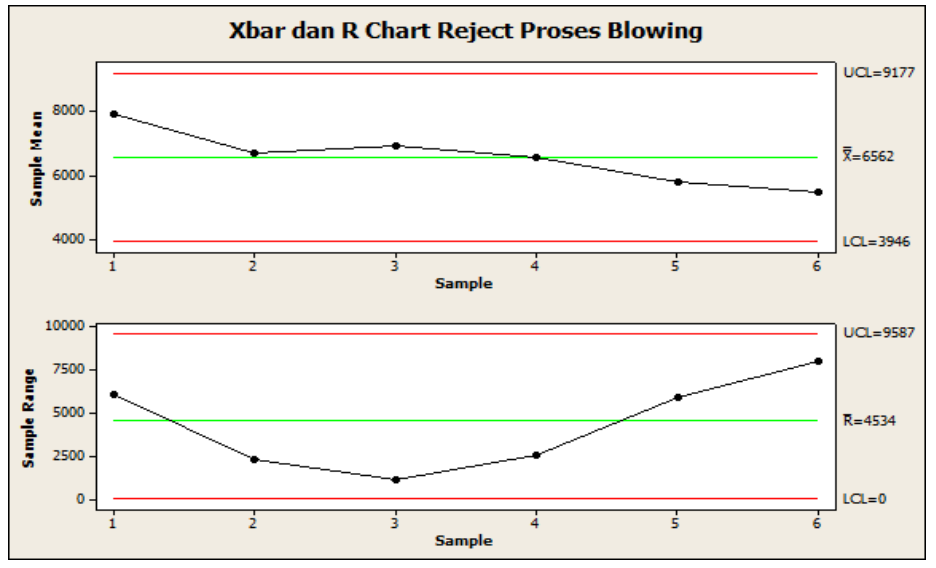

Fig. 4. Control Map X and R The period of the first semester in 2018 to the first semester in 2020 .

In Fig. 4. provide information that all processes are within the control limits as shown, so there is no need for revision, and the control chart is used in planning statistical process quality control of variable data use next period or future period.

From Table II it can be seen that the highest DPMO value was in Semester 2 in 2019 which was 9,505, while the lowest DPMO value was achieved in Semester 2 in 2018 which was 13,250. The initial value of DPMO obtained as the initial baseline for improvement is 11,366 with a sigma value of 3.78. This is important considering that the company's vision regarding quality is towards zero defects or product defects close to the value 0 or level sigma close to 6 sigma. 
European Journal of Business and Management Research www.ejbmr.org

TABLE II: AVERAGE PROCESS Sigma VALUE FOR 5 SEMESTERS

\begin{tabular}{cccc}
\hline No & TIME & DPMO & Sigma \\
\hline 1 & SEMESTER 1 2018 & 11.111 & 3.79 \\
2 & SEMESTER 2 2018 & 13,250 & 3.72 \\
3 & SEMESTER 1 2019 & 12,443 & 3.75 \\
4 & SEMESTER 2 2019 & 9.505 & 3.85 \\
5 & SEMESTER 1 2020 & 10,523 & 3.81 \\
\hline Semester 1 2018 - Semester 1 2020 & 11.366 & 3.78 \\
\hline
\end{tabular}

\section{Analyze}

Step Analyze is the stage after Measure of the DMAIC method. In this stage what needs to be done is to analyze why deviations or defects occur by looking for the causes that cause these defects. From the Pareto diagram at the measure stage, it is found that for the variant EKO.H the types of rejects that will be discussed are Nonstandard Size, Gusset Difference, Folding and Uneven Thickness, based on the Pareto results, the highest reject problem for the same reject type has the same handling so that an analysis based on variance is not carried out. Then there are five types of rejects that will be overcome, and various causes will be analyzed based on a causal diagram that has five analysis factors, namely Environment, Machines, Methods, Materials, and Humans and uses a fishbone diagram as follows:

\section{Fishbone Diagram}

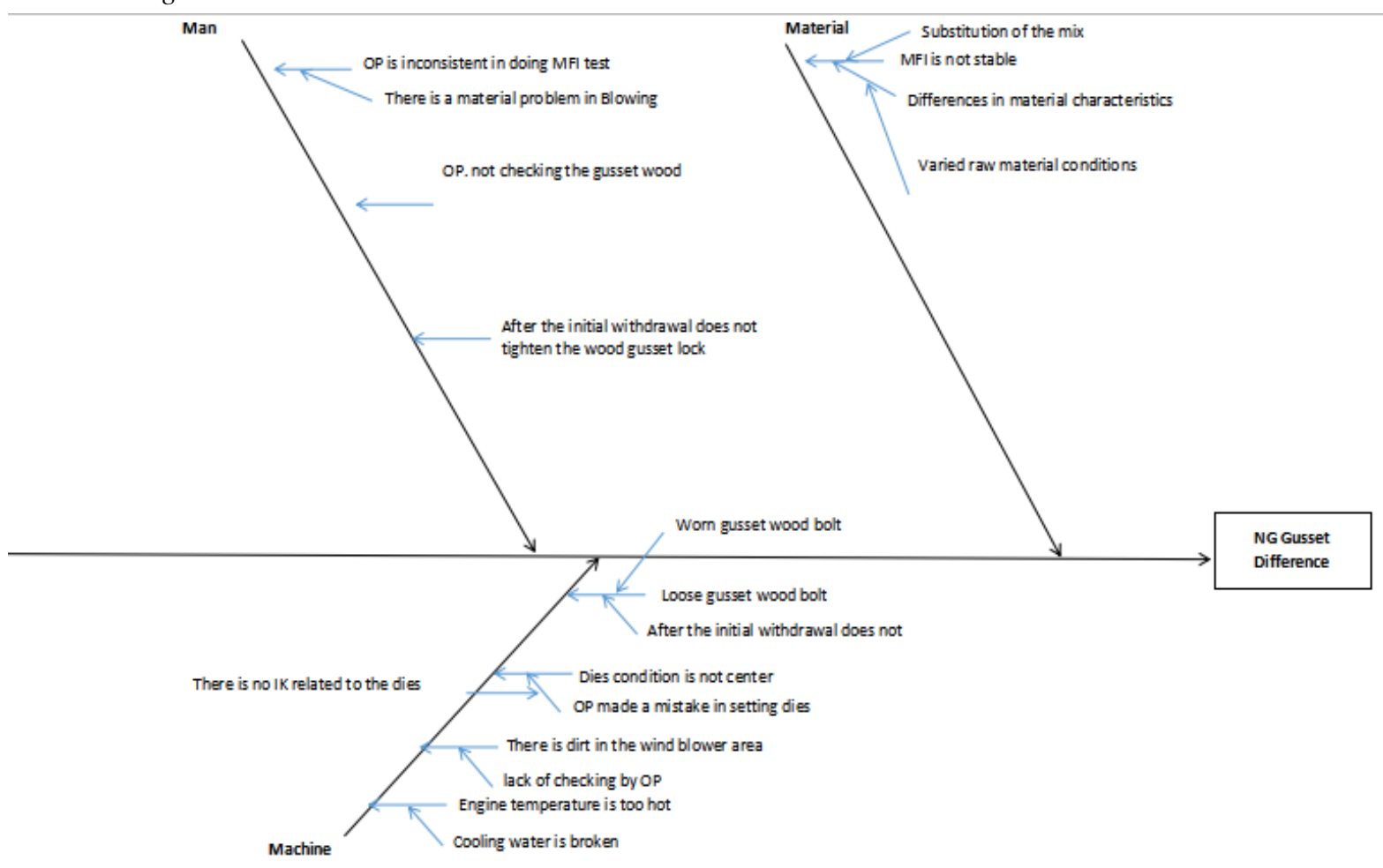

Fig. 5. Gusset Difference Fishbone Diagram.

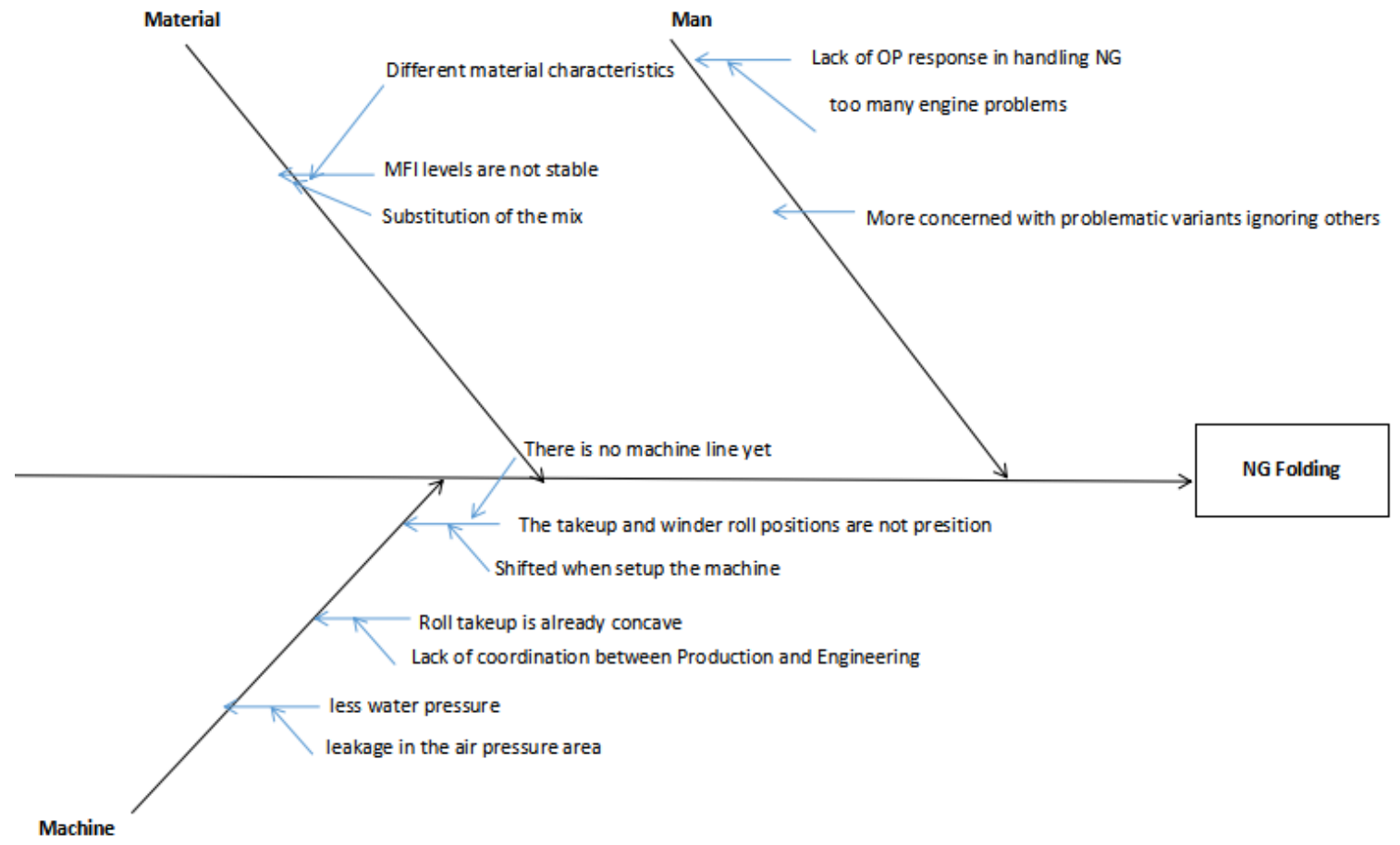

Fig. 6. Folded Fishbone Diagram 


\section{FMEA (Failure Mode and Effects Analyze)}

The RPN is obtained from multiplying the values on detection, Occurrence and Severity, which will then be explained through ranking there are four biggest problems that will be discussed in this study as shown in Table III.

\begin{tabular}{cccc}
\multicolumn{4}{c}{ TABLE III: RISK RANKING BASED ON RPN VALUE } \\
\hline No & Cause of Failure & RPN & Rank \\
\hline 1 & $\begin{array}{c}\text { Inhomogeneous material } \\
\text { characteristics }\end{array}$ & 280 & 3 \\
2 & $\begin{array}{c}\text { The takeup and winder roll } \\
\text { positions are not parallel }\end{array}$ & 252 & 4 \\
\hline
\end{tabular}

Table III informs that the ranking of the highest Risk Priority Number (RPN) values is at uneven skill setting dies with an RPN value of 294, Not taking measurements on the product after the initial recall with an RPN value of 294, Inhomogeneous material characteristics with an RPN value of 280, and the take up and winder roll positions are not aligned 252 .

Next is the last stage, which is to determine the appropriate action to be implemented or proposed improvements to improve the quality of plastic roll production in the blowing process to make it more efficient and optimal.

\section{3. $5 W+1 H$ Improvement Proposal}

After the FMEA analysis is carried out, the highest RPN value is used for proposed improvements at this stage. After measuring and analyzing the problems above, the next research activity here is to determine an action plan to improve quality by using the $5 \mathrm{~W}+1 \mathrm{H}$ technique for the root of the problem above. The results are presented in a table as follows:

TABLE IV: Not TAKing MEASUREMENTS On THE Product AFter

\begin{tabular}{|c|c|c|c|}
\hline Cause of Failure & $5 \mathrm{~W} 1 \mathrm{H}$ & Type & Description \\
\hline \multirow{6}{*}{$\begin{array}{l}\text { Inhomogeneous } \\
\text { material } \\
\text { characteristics }\end{array}$} & What & The main purpose & $\begin{array}{l}\text { To equalize the } \\
\text { characteristics of each } \\
\text { raw material }\end{array}$ \\
\hline & Why & $\begin{array}{l}\text { Why repairs need to } \\
\text { be made }\end{array}$ & $\begin{array}{l}\text { Due to the dominant } \\
\text { reject due to the problem } \\
\text { of too varied raw material } \\
\text { characteristics }\end{array}$ \\
\hline & Where & $\begin{array}{l}\text { Implementation } \\
\text { Location }\end{array}$ & Pelletizing \\
\hline & when & Execution Time & - \\
\hline & Who & Executor & Production operator \\
\hline & How & How & $\begin{array}{l}\text { Re-design of the plastic } \\
\text { seed storage silo in the } \\
\text { pelletizing process }\end{array}$ \\
\hline
\end{tabular}

Based on the results of brainstorming using fishbone and FMEA, the cause of the reject factor with the potential for inhomogeneous material characteristics to appear in several types of NG and become the highest RPN that must be overcome and improvement for the cause of this problem is to redesign the silo as in Fig. 7.
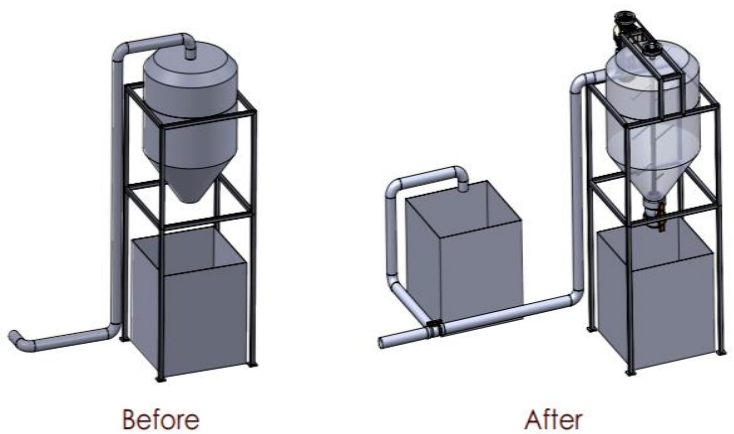

After
Fig. 7. Silo Redesign.

Fig. 7. explain that before going through the mixing and blowing process there is a pelletizing process where in this process, namely changing the raw plastic material into plastic seeds, in the process of making plastic seeds raw material has varied inputs so that when processed into plastic seeds it has different characteristics, one of which is Melt Flow Index (MFI) of melted plastic per 10 minutes, different MFI characteristics make the stability of the condition of the plastic balloon disturbed so that it can cause the potential for rejects to occur, so in order to have the same output characteristics, the seeds from the pelletizing process are put into a silo and the mixing process is carried out in order to minimize the number of characteristics of the raw materials produced.

TABLE V: Roll TAKEUP AND WindER POSITION NOT ALIGNED

\begin{tabular}{|c|c|c|c|}
\hline $\begin{array}{l}\text { Cause of } \\
\text { Failure }\end{array}$ & $5 \mathrm{~W} 1 \mathrm{H}$ & Type & Description \\
\hline \multirow{6}{*}{$\begin{array}{l}\text { The takeup and } \\
\text { winder roll } \\
\text { positions are } \\
\text { not parallel }\end{array}$} & What & The main purpose & $\begin{array}{l}\text { Due to minimize NG in } \\
\text { the blowing process }\end{array}$ \\
\hline & Why & $\begin{array}{l}\text { Why repairs need to } \\
\text { be made }\end{array}$ & $\begin{array}{l}\text { Because this problem is } \\
\text { something simple but has } \\
\text { a significant effect on } \\
\text { Quantity NG }\end{array}$ \\
\hline & Where & $\begin{array}{l}\text { Implementation } \\
\text { Location }\end{array}$ & Blowing \\
\hline & when & Execution Time & March \\
\hline & Who & Executor & Production operator \\
\hline & How & How & $\begin{array}{l}\text { Provide a boundary area } \\
\text { between the winder and } \\
\text { takeup so that they are } \\
\text { parallel }\end{array}$ \\
\hline
\end{tabular}

Based on the results of brainstorming using fishbone and FMEA the cause of the reject factor with the potential for not measuring the product after the initial withdrawal, this causes an increase in one type of $\mathrm{NG}$ and becomes the highest RPN that must be overcome and the improvement for the cause of this problem is to complete measuring tools in the blowing machine such as in Fig. 8.

Based on Fig. 8 is to provide area boundaries so that the winder and take-up roll machines are parallel This problem is something simple but has a significant effect on the quantity of NG. With this, it is expected that NG can be reduced.

\section{Control}

In this stage the results of the recommendations that have been given, at the control stage only socialize to related parties. 


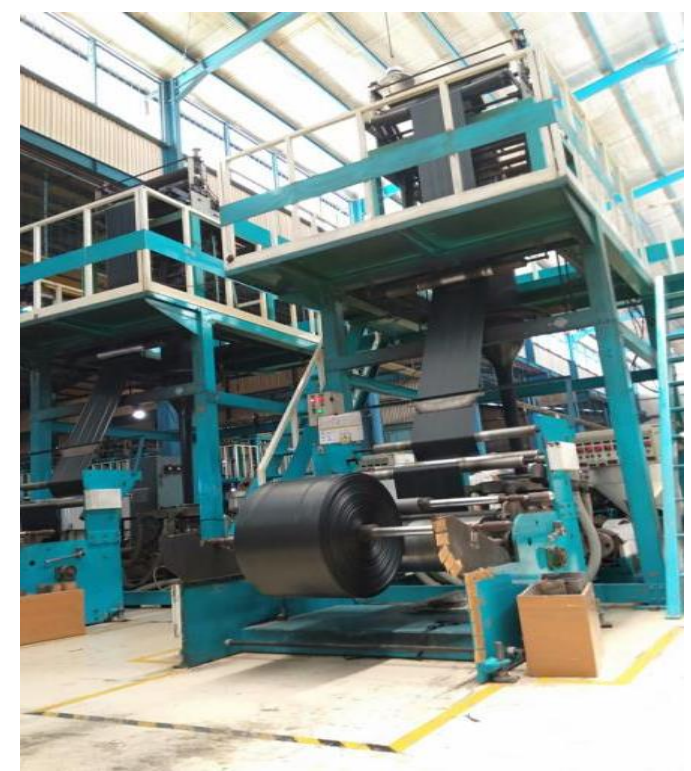

Fig. 8. Machine Line Limit.

\section{CONCLUSION}

Based on the results of the analysis above, it is obtained the initial DPMO value is 11,336 and the sigma value for the initial baseline is 3.78 . The DPMO and sigma values need to be increased. This is important considering the company's vision and mission related to quality is towards zero defects or product defects approaching a value of 0 or a sigma level approaching 6 sigma, to prioritize the causes of problems that must be addressed immediately, the first with an RPN value of 294, for the do 'minant cause factor is in the material characteristics which is not homogeneous, what is meant is where one of the influencing factors is the MFI value of the changing material where there is too much variability from the raw material with an RPN value of 280 and the last is the position of the roll take up and the winder is not parallel.

\section{REFERENCE}

[1] Alfi, Arga Santoso; Benawan, Didin Wahyudi, Sugeng Santoso (2020). Improvement of DEET level of Product X using Deming Cycle (PDCA Method) in PT Z, iCOMERA 2020, IOP Publishing, IOP Conf. Series: Materials Science and Engineering, 1034 (2021) 012110, doi:10.1088/1757-899X/1034/1/012110.

[2] Chase, Richard, B., Nicholas, J. A., \& Robert, J. (2005). Operation Management for Competitive Advantage. USA: McGraw-Hill Inc.

[3] Crosby, \& Philip, B. (1979). Quality is free: The Art of Making Quality Certain. New York: New American Library.

[4] Deming, W. E. (1982). Guide to Quality Control. Cambirdge: Massachussetts Institute of Technology.

[5] Dreachslin, J. L., \& Lee, P. D. (2007). Applying Six Sigma and DMAIC to Diversity Initiatives. Journal of Healthcare Management, 4, 361-367.

[6] Gaspersz, Vincent. Total Quality Management. Jakarta: PT. Gramedia Pustaka Utama. 2002.

[7] Gijo. E. V. (2011). Lean Six Sigma for Small and Medium Sized Enterprises: A Practical Guide. America: Taylor \& Francis Group.

[8] Juran, J. M. (1962). Quality Control Handbook. New York: McGrawHill.

[9] Larica, \&Litrone. (2013). Usulan Perbaikan Kualitas Dengan Penerapan Metode Six Sigma Dan FMEA Pada Proses Produksi Roller Conveyor MBC di PT XYZ. JurnalIlmiahTeknikIndustri.

[10] Mehrjerdi, Y. Z. Six Sigma: Methodology, tools and its future. Assembly Automation. 2011; 31 (1), 79 - 88.

[11] Montgomery, D. (2005). Quality Control (Fifith Edition ed.). New York: Arizona State University.
[12] Praharsi, Y., \& Maulana, D. (2020). Analisa kinerja bongkar muat dengan lean six sigma untuk mengurangi demurrage di pelabuhan PT. Petrokimia Gresik. Jurnal Manajemen Maranatha, 19(2), 105-114.

[13] Pzydek, \& Thomas. (2000). The Six Sigma Handbook: A Complete Guide for Greenbelts, Blackbelts\& Managers at all. New York: McGraw-Hill.

[14] Santoso, Sugeng; Putro, Septian Sugestyo; Fatmawati, Ari Ana; Putri, Caesarani Gloria; Sa'dillah (2021). Mitigation Design of the Risk of Covid-19 Transmission in a Labor-Intensive Industrial Environment using the FMEA Method, JKBM (Jurnal Konsep Bisnis dan Manajemen), 7 (2) Mei 2021, ISSN 2407-263X (Online), DOI: $10.31289 / \mathrm{jkbm} . v 7 \mathrm{i} 2.4674$.

[15] Santoso, Sugeng; Nusraningrum, Dewi; Hadibrata, Baruna; Widyanty, Winda; Isa, SalmiMohd; Apriyanto, Yoce; Henny (2021). Policy Recommendation for Food Security in Indonesia: Fish and Sea Cucumber Protein Hydrolysates Innovation Based, European Journal of Business and Management. ISSN 2222-1905 (Paper) ISSN 22222839 (Online), Vol.13 No.7, 2021, DOI: 10.7176/EJBM/13-7-08, Publication date: April 30 ${ }^{\text {th }}, 2021$.

[16] Santoso,Sugeng; Aulia, Muhammad Iqbal; Harahap, Rahmat Saleh; Sitorus, Rikki Sani; Waskita, Dedy Sandi (2021). Improvement of cooling time performance in TAD ${ }^{\circ} 20 \mathrm{t}$ mixing vessel using root cause analysis and PDCA cycle in TAD ${ }^{\circledR} 20 t$ mixing vessel product maturity, iCOMERA 2020, IOP Publishing, IOP Conf. Series: Materials Science and Engineering, 1034 (2021) 012126, doi:10.1088/1757-899X/1034/1/012126.

[17] Santoso, Sugeng; Dany Mayrifka; (2019). Analysis Problem and Improvement of Apperance Aesthetics Product Model HC C5/XT with Method of Plan-Do-Check-Act (PDCA) in PT XXXX, IJISRT 2019, International Journal of Innovative Science and Research Technology, ISSN No: 2456-2165.

[18] Stamatis, D. H. (2003). Failure Mode and Effect Analysis: FMEA from Theory to Execution. ASQ Quality Press. 